\title{
7. Reform and development strategy
}

\section{Justin Yifu Lin and Zhongkai Shen}

China is this year celebrating the fortieth anniversary of its reform and opening-up, marking the transition from a planned to a market economy. China's astonishing growth since 1978 is unprecedented in human history. In the first section of this chapter, we will review China's growth performance in the past four decades and the accompanying problems. In section two, we will analyse how it was possible for China to achieve such growth performance during but not before the transition, as well as why other transitional economies have not achieved a similar performance. Section three will analyse the causes of problems accompanying China's growth miracle and ways to overcome them. Section four will discuss China's growth potential and future outlook, while section five concludes the chapter with a discussion of the implications of China's growth miracle for other developing countries and for economics more generally.

\section{The growth miracle and its problems}

China has achieved remarkable success in the 40 years since its reform and openingup began in 1978. Before its transition from a planned to a market economy, China was one of the poorest countries in the world. Its per capita gross domestic product (GDP) in 1978 was just US\$156 - less than one-third of the average for sub-Saharan African countries, which was US\$490 in the same year. However, since then, dramatic changes have occurred in China. The annual GDP growth rate averaged 9.5 per cent from 1978 to $2017 .{ }^{1}$ China is now an upper-middle-income country, with a per capita GDP of US $\$ 8,640$ in 2017 measured by market exchange rates. In 1978, China accounted for only 4.9 per cent of the global economy-measured by purchasing power parity (PPP)—while this number increased to 18.6 per cent in 2016. Such a high rate of growth for such a long period has not occurred before in human history. Moreover, China has made a great contribution to the global fight against poverty. In 1978, about 81 per cent of people living in rural areas and 84 per cent of people with a living standard below the international poverty line of US\$1.25 per day. During the past 40 years, more than 700 million people in China have been lifted out of poverty. As is well known, to help developing countries grow and reduce poverty, many multilateral and bilateral development institutions were

1 Unless otherwise indicated, the statistics for the Chinese economy reported here come from the National Bureau of Statistics' China Statistical Abstract 2017, China Compendium of Statistics 1949-2008 and various editions of the China Statistics Yearbook, all published by China Statistics Press. 
set up after World War II. And yet, by 2000, if the number of people lifted out of poverty in China were subtracted from the world total, the number of poor people in the world increased rather than decreased.

Like other low-income countries before 1979, China was inward-looking. At that time, exports accounted for 4.1 per cent of China's GDP and imports for 5.6 per cent. In other words, about 90 per cent of Chinese GDP was not related to the global economy. However, from 1978 to 2016, the average annual growth rate of trade was 14.8 per cent. China's trade dependency ratio (trade to GDP) reached 32.7 per cent in 2016. With such dramatic growth performance, in 2009, China overtook Japan to become the second-largest economy in the world. In 2010, it overtook Germany to become the largest exporting country in the world. In 2013, it overtook the United States to become the largest trading country in the world; the total volume of Chinese exports and imports was larger than that of the United States. In 2014, China overtook the United States to become the largest economy in the world, measured by PPP.

Poverty, disease and illiteracy are usually considered fundamental issues for a developing country. With such great economic progress, the wellbeing of people in China has been significantly improved. Average life expectancy increased from 67.8 years in 1982 to 74.83 years in 2010. In 1982, more than one in five Chinese were illiterate and only 6.78 per cent had received education to senior high school or middle special school level and above. By 2010, China's illiteracy rate was reduced to 4.08 per cent and more than 14 per cent of citizens had been educated to senior high or middle special school level and above.

China's dynamic growth has also contributed to global growth and stability. During the Asian Financial Crisis in 1997, China maintained the stability of its exchange rate and dynamic growth of its economy and helped the East Asian economies' quick recovery. By 2000, only three years after the crisis, East Asia was once again the fastest growing region in the world. China was the first country to recover from the 2008 Global Financial Crisis (GFC), in the first quarter of 2009, and has contributed more than 30 per cent of global growth annually since then.

China's influence in global governance has increased with its economic growth, and it is now the third largest shareholder of the World Bank and the International Monetary Fund (IMF). China has also championed its ambitious Belt and Road Initiative (BRI), which proposes to build infrastructure to connect markets in Asia, Europe and Africa. Despite open opposition from the United States at its inception, the Asian Infrastructure Investment Bank (AIIB) — proposed by China as a vehicle for the BRI-has 77 member countries today, making it one of the largest multilateral development institutions in the world. In 2015, the renminbi was listed as one of five currencies in the IMF's Special Drawing Rights (SDR) basket, alongside the American dollar, the Japanese yen, the euro and the British pound. This designation moved the renminbi one step closer to becoming an international reserve currency. 


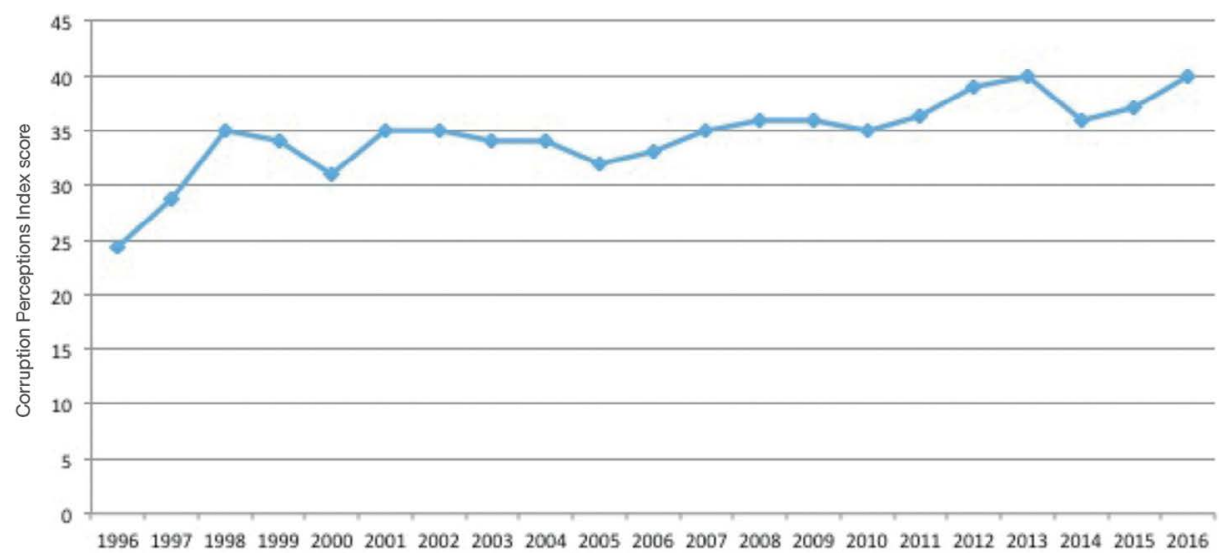

Figure 7.1 China's score on the Corruption Perceptions Index, 1996-2016 Note: The Corruption Perceptions Index ranges from 0 to 100. The lower the score in a country is, the higher is the perception of corruption in the country.

Source: Transparency International (2017).

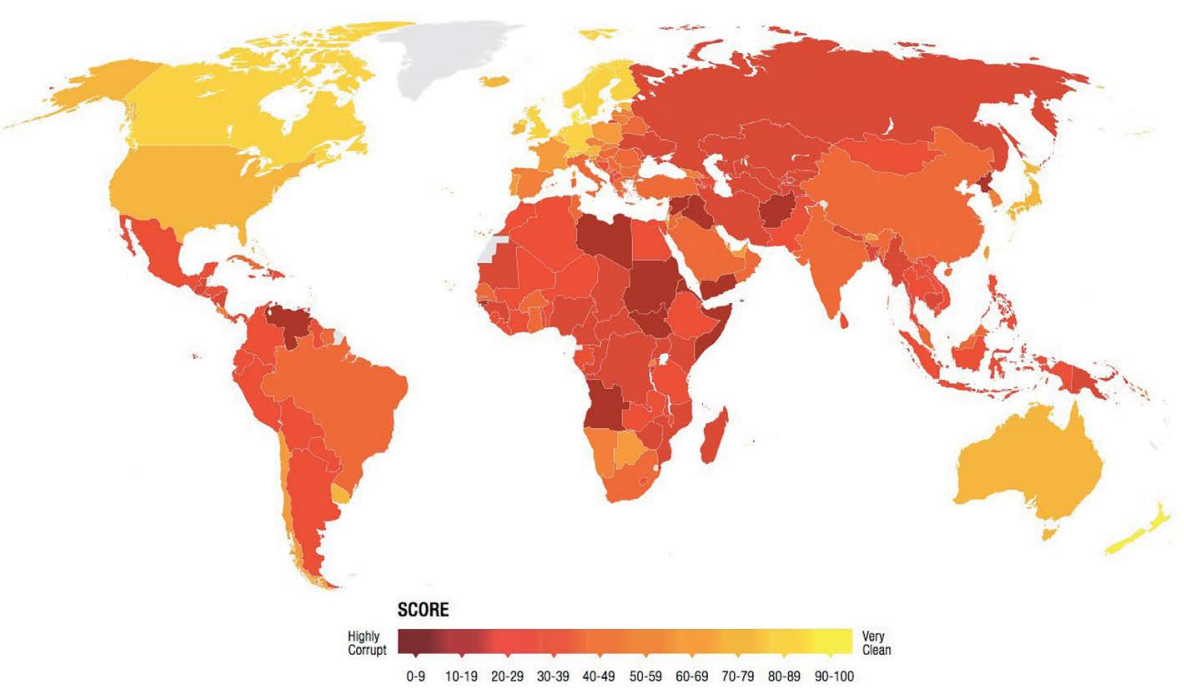

Figure 7.2 Corruption Perceptions Index scores of 176 countries/territories in 2016

Source: Transparency International (2017).

China's extraordinary growth has, however, come at a considerable cost. In addition to environmental degradation and food safety issues-the result of rapid industrialisation and lack of appropriate regulations-China's Gini coefficient, a commonly used measure of inequality, reached 0.465 in 2016, which is above the international warning line of 0.45 . Closely related to income inequality is corruption. Transparency International (TI) has published its Corruption Perceptions Index annually since 1996, ranking countries by their perceived levels of corruption, as 
determined by expert assessments and opinion surveys. The index currently ranks 176 countries on a scale from 100 (very clean) to 0 (highly corrupt). According to TI data, China's average annual score on the Corruption Perceptions Index was 34.6 from 1996 to 2016, indicating a relatively high degree of corruption (Figure 7.1). China was ranked 79 of the 176 countries or territories in the index (Figure 7.2).

\section{China's miracle in historical and international perspective}

\section{Why was China able to achieve such extraordinary growth during its transition?}

Why was China able to grow so dynamically during the reform period? Our answer is simple: the latecomer advantage.

Rapid and sustained growth in per capita income is a modern phenomenon. Based on the studies of Maddison (2001), average annual per capita income growth in the West was only 0.05 per cent before the eighteenth century, rising to about 1 per cent in the nineteenth century and reaching about 2 per cent in the twentieth century. Therefore, to understand how China was able to grow so rapidly during the past four decades, one needs to understand the nature of modern economic growth.

As mentioned, China's per capita GDP increased continuously, from US\$155 in 1978 to US\$8,600 in 2016. Achieving this kind of continuous growth requires a continuously rising level of productivity, the foundations of which are technological innovation and industrial upgrading. Technological innovation in existing industries will improve their level of productivity, while industrial upgrading allows the reallocation of resources from low to higher value-added sectors. This process of innovation and upgrading is the foundation of continuous productivity and income growth in any nation-developed and developing. Furthermore, to realise the potential of new technologies and industries, improvements in both hard infrastructure, such as power and road networks, and soft infrastructure, including legal frameworks and financial institutions, are required to reduce transaction costs and share risks.

In advanced high-income countries, technological innovation and industrial upgrading require costly and risky investments in research and development (R\&D) as their technologies and industries are already at the global frontier. To upgrade, therefore, they have to invent new technologies and industries to move these frontiers forward. Moreover, the institutional innovation required to realise the potential of new technology and industry often follows a costly trial-and-error, path-dependent 
evolutionary process (Fei and Ranis 1997). From the end of the nineteenth century until now, the average annual growth rate of per capita GDP and per capita labour productivity in high-income countries was about 2 per cent per year.

Developing countries, however, can acquire, imitate or borrow technologies, industries and institutions from the advanced high-income countries during the catch-up process. In this way, technological innovation and industrial upgrading in developing countries involve lower costs and fewer risks than in high-income countries. This is the so-called latecomer advantage. If developing countries are able to fully exploit this advantage, they can achieve higher rates of technological innovation and industrial upgrading than the advanced high-income countries. Thus, it is possible for them to grow at an annual rate several times that of highincome countries for decades before closing the income gap.

In the postwar period, only 13 of the world's economies achieved continuous annual GDP growth rates of 7 per cent or more for 25 years or more (World Bank 2008). The Commission on Growth and Development, headed by Nobel Laureate Michael Spence, found the first of five common features of these 13 economies was their ability to tap the potential of the latecomer advantage - that is, they 'imported what the rest of the world knew and exported what it wanted' (World Bank 2008: 22).

China adopted its opening-up strategy and tapped the latecomer advantage in 1978, joining this group of 13 economies. Effectively exploiting the latecomer advantage has allowed China to emerge as the world's workshop and achieve sustained rapid economic growth for a long period.

\section{Why was China unable to attain similar success before its transition started?}

If the latecomer advantage was the reason for China's extraordinary growth performance after 1978, the same advantages should have existed for centuries before 1978, so why did China not benefit before the reform and opening-up? Again, our answer is simple: because China voluntarily gave up the latecomer advantage.

When the People's Republic of China (PRC) was established in 1949, China accounted for 4.2 per cent of the global economy, but this number increased to only 4.9 per cent by 1978 . This came about because China adopted the wrong development strategy at that time and therefore failed to exploit the latecomer advantage.

As is well known, China was the largest economy and among the most advanced, powerful countries in the world before modern times (Maddison 2007). Like many other Chinese social and political elites, Mao Zedong and other first-generation revolutionary leaders were inspired by the dream of achieving rapid modernisation to make people rich and the nation as powerful as the developed countries. To achieve 
an income level as high as the developed countries required China to have the same advanced industries as high-income countries to reach the same level of labour productivity. Creating a system of national defence as strong as that in high-income countries required defence industries capable of producing equally sophisticated military equipment. Thus, the lack of industrialisation in China-especially of the large, advanced, capital-intensive heavy industries that were considered the foundation of high labour productivity and military strength-was regarded as the key reason for China's backwardness.

Starting in 1953, China adopted a series of ambitious five-year plans to accelerate the building of modern advanced industries, with the goal of overtaking the United Kingdom within 10 years and catching up with the United States within 15 years. These advanced industries were related to national defence, the knowhow for which was not freely available and, in fact, was embargoed for China. Faced with these challenges, China had to 'reinvent the wheel' and do its own research to acquire these technologies. In so doing, China voluntarily chose to forgo the potential of the latecomer advantage.

Moreover, China did not have comparative advantages in the priority industries at that time. In 1953, 83.5 per cent of the labour force was employed in the primary sector, and China's per capita GDP, measured by PPP, was only 4.8 per cent of that of the United States. Given China's endowment structures and income level, it did not possess a comparative advantage in these industries, which were extremely capital intensive. Firms in these industries therefore lacked viability in an open, competitive market. They could not develop spontaneously according to market forces. The only way to develop and sustain these industries was for the state to use administrative measures to mobilise and allocate resources to priority industries and give protection and subsidies to the nonviable firms by distorting the prices of capital and other inputs. Firms in the priority industries were also given a market monopoly and thus enjoyed monopoly prices.

These interventions and distortions enabled China to quickly build up modern advanced industries, test nuclear weapons in the 1960s and launch satellites in the 1970s. Undoubtedly, these were significant achievements. However, resources had been misallocated, the incentives were distorted and the labour-intensive sectors in which China had a comparative advantage were depressed. Thus, by the 1970s, although China had established most of the modern industries of the day, it remained a poor country with more than 80 per cent of its population employed in agriculture.

Only after 1978, with the reform and opening-up, did China start to develop the sectors in which it had comparative advantages - that is, labour-intensive light manufacturing. China's labour costs were low and so were competitive in domestic and international markets. Earning high profits in the light manufacturing sectors, China quickly accumulated capital, paving the way for its industrial upgrading. 
In this process, China finally started to benefit from the latecomer advantage. This is why our explanation for China's failure to grow as rapidly before 1978 as it did after that time is so simple: the wrong development strategy deprived China of the ability to benefit from its long-existing potential for rapid growth.

\section{Why did few other transitional economies perform equally well?}

The attempt to build large-scale modern industries on an agrarian base occurred not only in China, but also in other socialist and nonsocialist countries after World War II. The development of modern advanced industries was considered the only way to achieve rapid economic take-off and eliminate poverty (Prebisch 1950). Development strategies oriented towards heavy industries and import substitution became popular after the 1950s among developing countries (Lal and Mynt 1996). To implement such development strategies, as China had, these countries introduced distortions and interventions, which caused economic inefficiency. As a result, after World War II, while high-income countries grew at about 2 per cent per year, the average annual per capita GDP growth rate of most developing countries was less than 2 per cent, and thus the income gap between high-income and developing countries increased rather than decreased (Maddison 2001).

While China embarked on its transition from a socialist planned to a market economy in 1978, many other countries embarked on transitions under the guidance of the World Bank and the IMF in the 1980s and 1990s. Compared with China's stable and continuous economic growth, other countries suffered from economic collapse, stagnation and frequent crises. It is natural to ask why most other transitional economies did not perform as well as China. Our answer to this is also simple: because other economies followed the wrong transition strategy.

When they began their transition, many countries followed the neoliberal 'Washington consensus', which was based on the argument that the misallocation of resources caused by excessive government intervention led to unsatisfactory economic performance. Based on this logic, to improve their economic performance, socialist and developing countries were advised to adopt a 'shock therapy' approach of privatisation, marketisation and stabilisation to immediately remove all distortions, end government intervention and allow markets to function freely. However, such distortions and interventions were endogenous to the needs of protecting nonviable firms in priority sectors. If these distortions were removed suddenly, these large-scale industries would go bankrupt, resulting in high unemployment and acute social disorder. Many such heavy industries formed the backbone of the military industry and national defence. After trying the Washington consensus shock therapy, many countries reintroduced subsidies and protection through the back door to preserve large-scale industries for the purpose of providing jobs and securing their national defence. 
Compared with the distortions before transition, the newly introduced distortions were even more inappropriate and more inefficient. There is convincing evidence to support this argument. For example, in Russia today there are eight oligopolies in military-related heavy-industry sectors. After privatisation and all kinds of crises, these oligopolistic groups received greater subsidies and protection than they had under the former Soviet Union. Similar situations prevail in other Eastern European and in Latin American and African countries. This is because after privatisation managers of firms in priority sectors had greater incentive to ask for subsidies, which could be simply used to build their own personal wealth. In contrast, before privatisation, this would have amounted to corruption and would be punishable. Furthermore, because of soft budget constraints, managers would ask for even higher subsidies. As a result, reform led first to a certain degree of chaos followed by stagnation and frequent crises (Lin 2014).

China also embarked on a transition from this type of distorted economy, but it managed to maintain stability and dynamic economic growth. The main reason for this is that China adopted a pragmatic, gradual and dual-track approach: understanding that existing sectors could not survive without protection and subsidies, the government continued to provide them for as long as was required. Meanwhile, the Chinese Government also liberalised entry into new sectors, most of which were labour-intensive and small-scale traditional sectors. After lifting the repression of these sectors in 1979, Chinese and foreign firms were allowed to enter these industries. Indeed, the Chinese Government not only liberalised, but also actively facilitated and supported entry into, industries that were consistent with China's comparative advantage at that time as a labour-abundant country.

To turn the comparative advantage into competitive advantage, China also needed to provide adequate infrastructure and a good business environment. However, in 1979 and the 1980s, infrastructure in China was extremely poor, and a lack of financial resources meant it was impossible to improve infrastructure nationwide. Given the limited resources, the Chinese Government set up special economic zones (SEZs), industrial parks and export zones, improving infrastructure in a limited number of areas. Moreover, in SEZs and other economic zones, all distortions were removed, leading to a good business environment. In addition, a wide range of services - for example, comprehensive business services—were provided in the SEZs and industrial parks. As a result, new industries consistent with China's comparative advantage could utilise the infrastructure, business environment and services in these zones and make themselves competitive in international markets.

It was for these reasons that Chinese exports increased rapidly after 1978. A few other socialist economies, such as Poland, Slovenia and Vietnam, adopted a similar dual-track approach and achieved outstanding performance in their transitions. Thus, utilising a gradual, dual-track approach and the latecomer advantage during 
its transition, China accumulated capital quickly and Chinese industries gradually upgraded from labour-intensive to capital and technology-intensive in the dynamic economic growth process.

\section{The causes of remaining problems and the way out}

\section{Reasons for the remaining problems}

The gradual, dual-track approach to transition is, however, a double-edged sword. While it has enabled China to achieve stability and dynamic economic growth, it has also created a series of problems, especially corruption and disparities in income distribution.

The protections and subsidies within the dual-track transition were endogenous to the needs of protecting nonviable firms in priority capital-intensive industries, which went against China's comparative advantages. One of the most important costs for these industries was that of capital. While fiscal appropriation was provided before the start of the transition in 1979, the source of capital for these industries shifted to bank loans and the equity market. Four large state banks and a stock market were set up to meet the capital needs of large enterprises in the 1980s. Given that firms in these industries were nonviable, they required subsidies. As a result, interest rates and capital costs were artificially repressed. Therefore, whoever had access to banks' credit services or the stock markets would be subsidised. In 1979 and the 1980s, all firms in China were state owned. Gradually, success in new sectors saw some domestic firms grow to become large enterprises. These large firms could also receive subsidies by borrowing from the large state banks or by listing on the stock market. These subsidies were in fact paid for by households, farms and small and mediumsized industrial and service firms who put their money into the banking sector or the stock market and who were poorer than the owners of the enterprises they financed. The subsidisation of the operations of rich people's firms by poorer people was one of the most important drivers of increasing income disparities.

Moreover, this financial repression created economic rents accruing to whoever had access to financial services, resulting in rent-seeking, bribery and corruption.

Before 1979, in accordance with the provisions of the Chinese constitution, all natural resources were 'owned by the state-that is, by the whole people'. At that time, natural resources were managed free of charge by large-scale state-owned enterprises (SOEs) and were provided to those enterprises at very low prices. After 1979 , the government allowed private firms to enter the mining sector and liberalised 
price controls, while maintaining low concession fees due to the state-owned mining enterprises' need to cover expenditure on redundant and retiring workers. Thus, the newly established private mining enterprises, which had no redundant or retired workers, could become rich overnight. In addition, monopoly rents existed in large service sectors, such as telecommunications and finance. These were another cause of inequality and corruption.

Another problem was environmental pollution, which worsened with the rapid development of manufacturing, which has high energy and emissions intensities compared with agriculture and services, and uses massive amounts of coal. Pollution in China is therefore related to its development stage, and can be mitigated by environmental regulation and supervision, and will be much improved when China becomes a high-income, service-dominated economy.

\section{How to deepen reform?}

The main reason for maintaining transitional distortions was the need to protect nonviable SOEs in comparative advantage-defying, capital-intensive industries. After 40 years of dynamic growth and capital accumulation, many of these industries are now consistent with rather than defying China's comparative advantages and firms in these industries have become viable in open, competitive marketsincluding internationally.

The reason for maintaining distortions has disappeared. It is time for China to complete its transition and remove all remaining distortions-specifically, by removing financial repression and allowing the development of small financial institutions and local banks to provide credit services for agricultural households and small and medium-size enterprises. Furthermore, it is necessary to remove the retired workers' pension burden from the stated-owned mining sector and impose taxes on the natural resource sector. It is also essential to encourage access to and competition in the service sectors where large monopoly rents remain, such as telecommunications and the energy and financial sectors.

Indeed, the above measures were among those in the reform agenda announced by the Chinese Government at the third plenary session of the eighteenth party congress. During his first five-year tenure as national leader, in 2012-17, President Xi Jinping engaged the assistance of his ally Wang Qishan in a sweeping anticorruption drive. He proposed allowing the market to play a decisive role in resource allocation by eliminating the remaining distortions in the dual-track reform system; and advocated for tight environmental regulation, which would balance high growth with 'green' growth. Hopefully, the implementation of a reform agenda of this kind and the removal of these distortions will eliminate the root causes of income inequality and corruption. 


\section{The new normal and China's economic outlook}

China's annual GDP growth rate dropped from the average annual rate of 9.6 per cent in the period 1978-2016 to 6.7 per cent in 2016 (Figure 7.3). The reason for this slowdown is hotly debated in China and the debate is closely followed globally. To answer the question of whether China can maintain its dynamic economic growth in the coming years, one needs to know the size of China's growth potential and the reasons for the deceleration of growth since 2010 .

Many economists thought the deceleration was due to the decline of growth potential after more than three decades of extraordinarily high growth as well as domestic structural problems.

We will first estimate China's growth potential and analyse the main cause of recent growth deceleration.

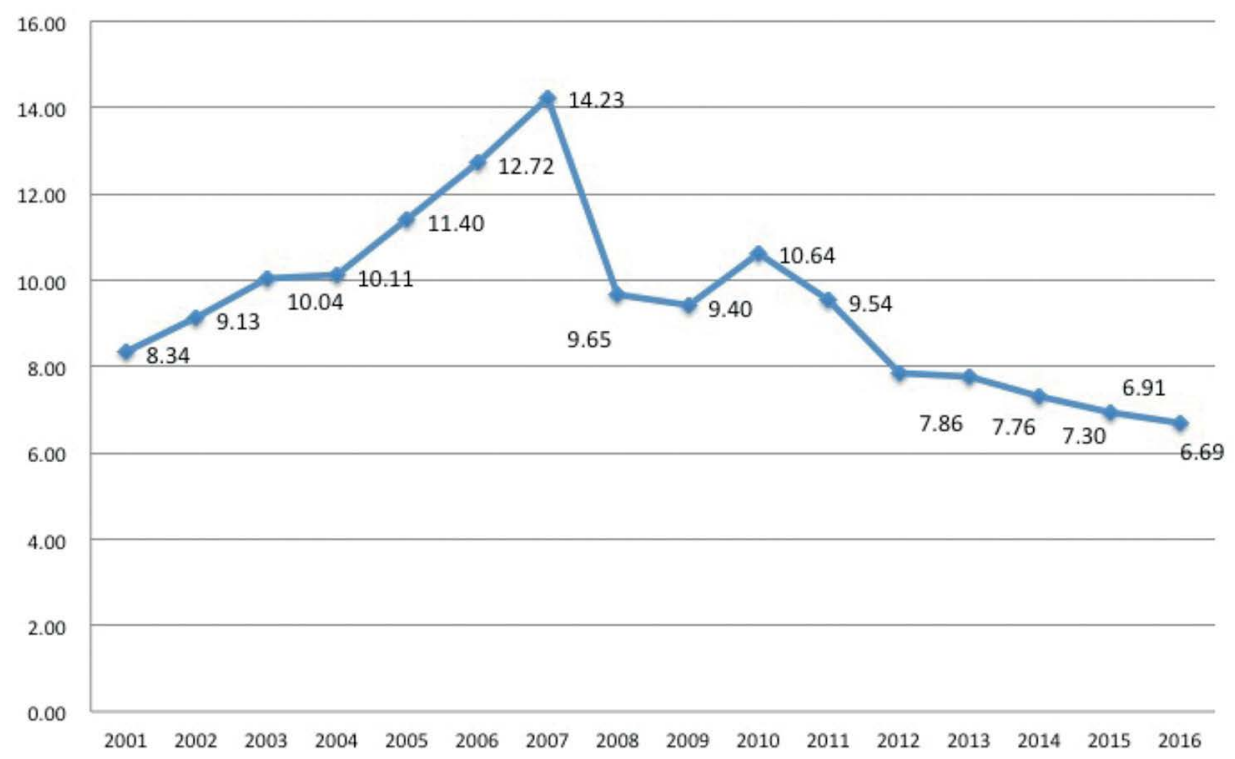

Figure 7.3 China's GDP growth rate, 2001-16 (constant 2010 US\$)

Source: World Bank (2018).

\section{How large is China's growth potential?}

China's potential for rapid economic growth depends on the size of the latecomer advantage it still enjoys. To measure this, one should compare China's per capita GDP with the per capita GDP of high-income countries such as the United States, because per capita GDP is a proxy for a country's average labour productivity, which is a measure of the degree of technological advancement and industrial valued added. 
Measured by PPP, in 2008, China's per capita GDP was 21 per cent of that of the United States (Maddison 2010). This status relative to the United States was similar to that of Japan in 1951, Singapore in 1967, Taiwan in 1975 and South Korea in 1977 -all of which stood at 21 per cent.

In the following 20 years, Japan grew at an average annual rate of 9.2 per cent, Singapore grew at 8.6 per cent, Taiwan grew at 8.3 per cent and South Korea grew at 7.6 per cent. After 20 years of dynamic economic growth, Japan's per capita income, measured in PPP, was 65.5 per cent of that of the United States in 1971, while Singapore was 53.9 per cent in 1987, Taiwan was 54.2 per cent in 1995 and South Korea was 50.2 per cent in 1997. These four Asian economies were among the 13 referred to above as having tapped into the growth potential deriving from the latecomer advantage and as enjoying high growth rates of 7 per cent or more for 25 or more years.

Just as these economies were able to utilise the technology gap and exploit the latecomer advantage to grow for 20 years at between 7.6 per cent and 9.2 per cent per year, China has the potential to grow at 8 per cent per year for 20 years after 2008 .

\section{What were the reasons for the deceleration of China's growth to below its potential after 2010?}

If China's potential growth rate was 8 per cent, why has that growth decelerated to below 8 per cent? The potential growth rate is estimated according to supplyside technology; however, moving from potential to its realisation depends also on demand-side conditions.

To answer this question, let us come back to the GDP accounting identity-that is, $G D P \equiv C+I+G+N X$. From a demand-side perspective, keeping government expenditure unchanged, there are three components of GDP: exports, investment and consumption. This shows that, from the demand side, the deceleration was the result mainly of declining growth rates of exports and investments due to external and cyclical factors.

First, high-income countries_-including the United States, Western European countries and Japan (Figure 7.4) — have not yet recovered from the GFC of 2008; in these countries, the GDP growth rate was less than 3 per cent per year, which was the average level for high-income countries before the GFC. As a result, household income stagnated. In addition, households had large debt burdens before the GFC that they need to reduce. These factors contributed to stagnation of household consumption in these countries and depressed international trade, with a major negative impact on Chinese exports, as China is a major global supplier 
of consumption goods. From 1978 to 2016, China's average annual export growth was about 15.3 per cent; in 2016 , it was about -7.7 per cent. This downturn was one of the reasons for the deceleration of Chinese growth.

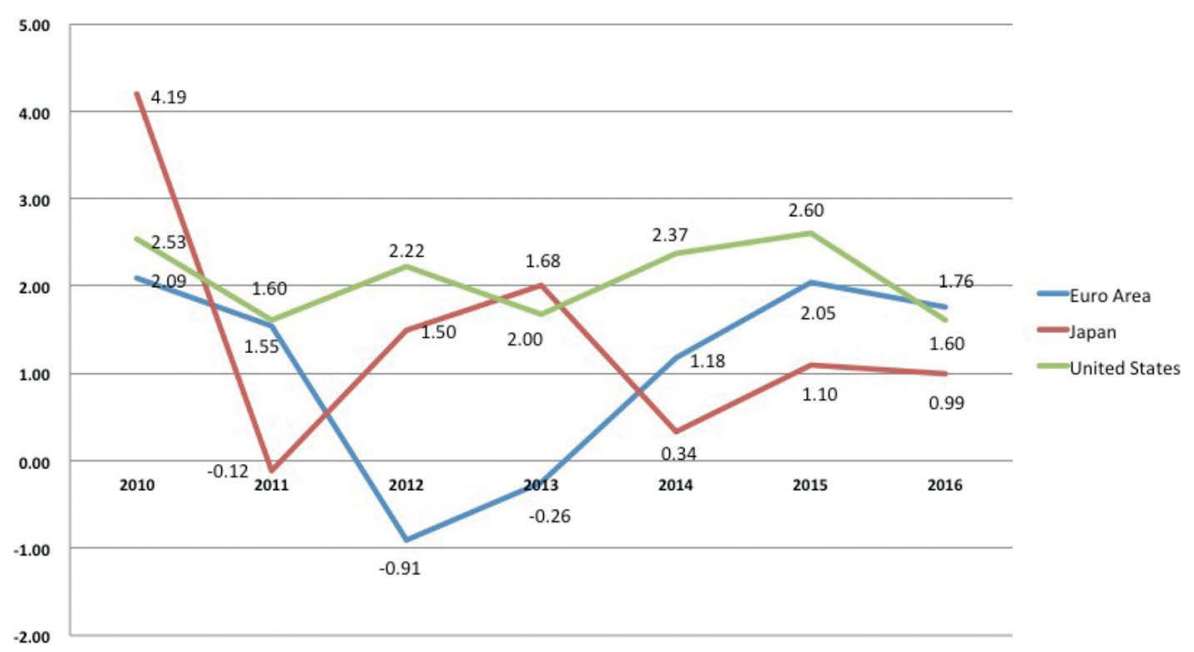

Figure 7.4 GDP growth rates of high-income countries, 2010-16 (constant 2010 US\$)

Source: World Bank (2018).

The second reason for the deceleration was that, to deal with demand shock from the GFC, most countries adopted a countercyclical fiscal expansion to support investment. These projects were mostly completed; nevertheless, the global economy has not fully recovered. The private sector's incentives for investment remain low. Without a new round of stimulus programs, investment growth rates will drop.

As for consumption, since China maintains a high employment rate, household income has continued to grow rapidly, at about 8 per cent per year, with consumption growing at a similar rate. The growth of consumption is the reason the country has managed to maintain a growth rate of about 7 per cent per year.

The above two factors affected not only China, but also other countries, causing the other BRIC members (Brazil, Russia and India) (Figure 7.5) and exportoriented high-income/high-performance East Asian economies to experience a similar pattern of deceleration, as shown in Figure 7.6. As their household income and consumption did not grow as rapidly as China's, their growth deceleration was even sharper than China's.

In short, although China as a transitional economy has many internal structural problems, the deceleration since 2010 is due mainly to external and cyclical factors. 
China's 40 Years of Reform and Development: 1978-2018

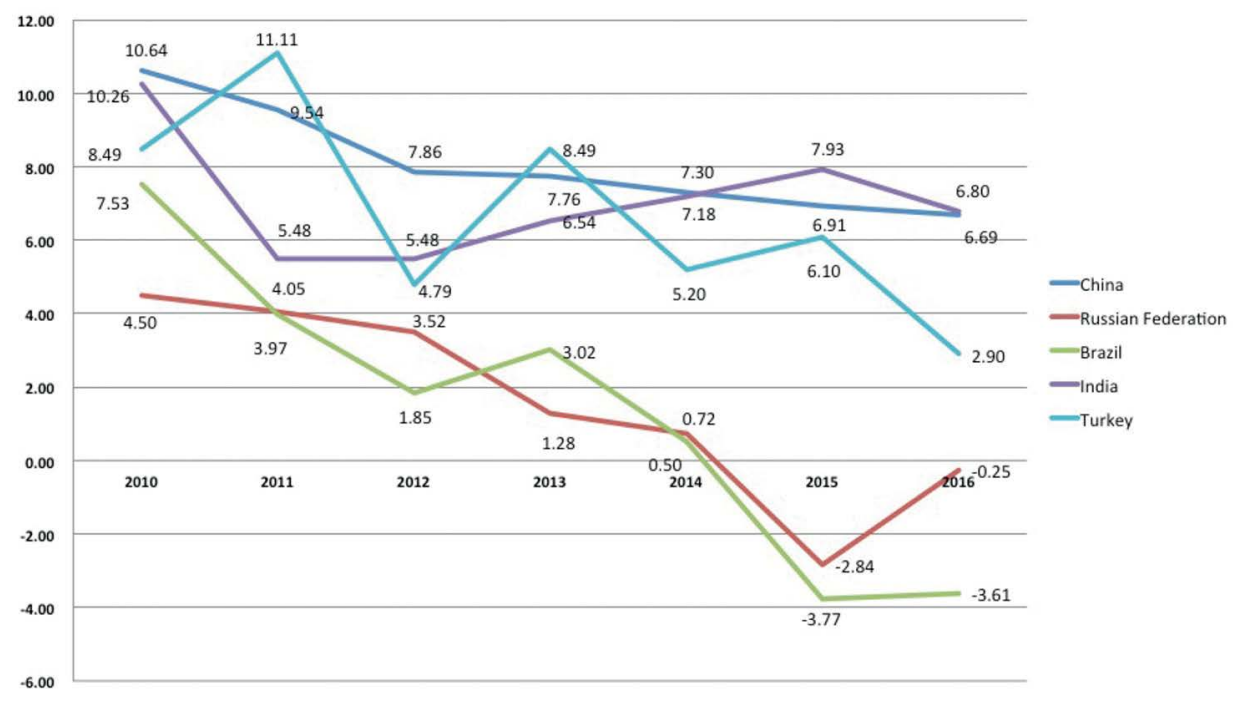

Figure 7.5 GDP growth rate in BRIC countries and Turkey, 2010-16 (constant 2010 US\$)

Source: World Bank (2018).

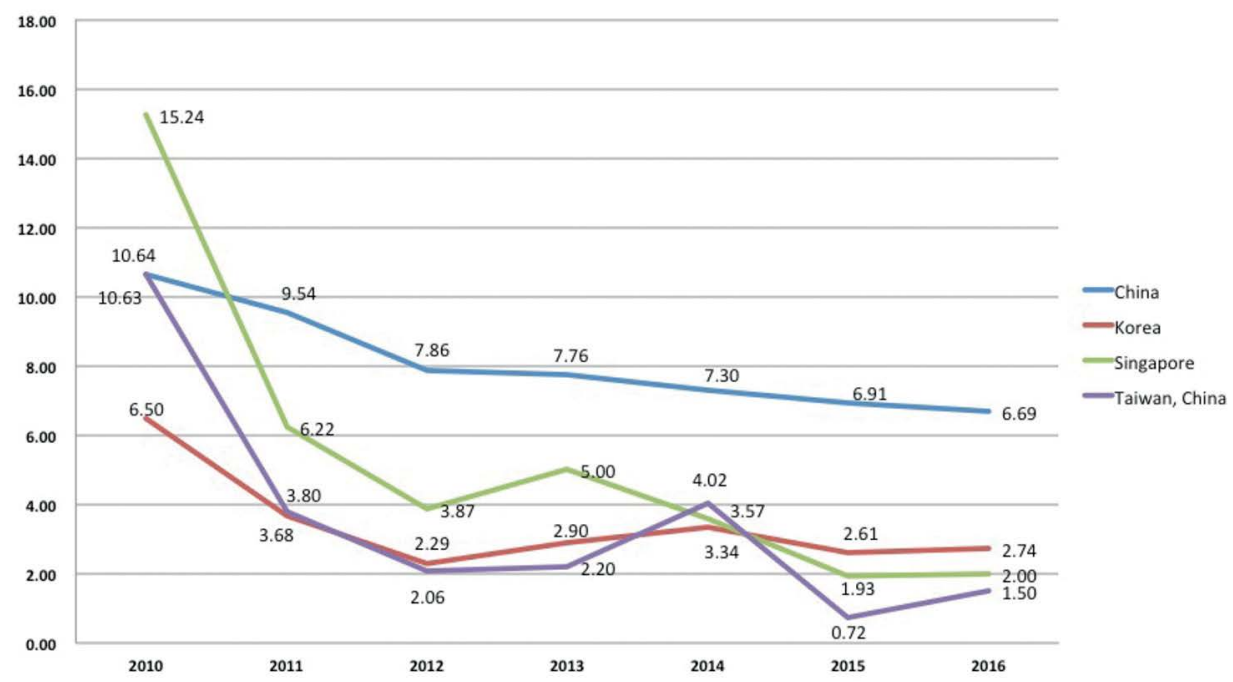

Figure 7.6 GDP growth rate in high-performance export-oriented countries, 2010-16 (constant 2010 US\$)

Source: World Bank (2018). 


\section{China's economic outlook}

So, how can China maintain a relatively high growth rate in coming years? Or, what are the advantages China can make use of to drive its dynamic growth? As is well known, due to a lack of fundamental structural reforms, Japan stagnated after the burst of its economic bubble in 1991. High-income countries are likely to suffer a similar fate-growing at less than the normal rate of 3 per cent per year and repressing global trade. Therefore, given sluggish external demand, China's growth will come mainly from domestic demand.

As a middle-income developing country, China still has plenty of good opportunities for investment in industrial upgrading, urban and interurban infrastructure and environmental protection, in spite of the excess capacity in many sectors. Another advantage is that China has a very sound fiscal position. In 2015, national, provincial and local government debt was less than 60 per cent of GDP - among the lowest in the world. In addition, China still has more than US\$3 trillion in foreign exchange reserves - the largest in the world. With good investment opportunities and abundant financial resources, China will maintain a reasonable rate of investment growth, creating jobs and increasing household incomes and consumption. Under these conditions, there is no reason for China not to reach its annual growth target of 6.5 per cent or more in the coming years. If China does maintain such a growth rate, it is very likely that, by as early as 2020 or no later than 2022, its per capita GDP will reach or pass the threshold of US\$12,700, making China a high-income country (Lin et al. 2016). By 2030, China will become the largest economy in the world, measured by market exchange rates. It is very likely China will be the third economy_following Taiwan and South Korea-among more than 200 developing economies to successfully develop from a low-income to a high-income economy since World War II.

\section{What are the implications of China's growth miracle for other developing countries and for economics?}

Are there useful lessons that can be drawn from China's experiences over the past 40 years? Absolutely.

First, as long as they know how to make full use of their comparative advantages in their industrial development and as long as they tap the latecomer advantage in technological innovation and industrial upgrading, all developing countries have the opportunity to grow at 8 per cent or more for several decades. For this to happen, a country needs to have an efficient market and a facilitating government. A well- 
functioning market is a precondition for the development of industries according to a country's comparative advantage, since only with such a market can relative prices reflect the relative scarcities of factors in the economy and guide entrepreneurs to adopt technologies and enter into industries consistent with the comparative advantages determined by the economy's factor endowments. A facilitating government is also essential to compensate the first movers' externalities and remove bottlenecks in hard infrastructure and soft institutions to reduce transaction costs in the process of technological innovation and industrial upgrading. Once entrepreneurs follow the comparative advantage to develop specific industries in a competitive market and the state plays a facilitating role to turn those industries to competitive advantage, capital accumulation will be rapid, comparative advantages will change rapidly and the economy can tap into the potential of the latecomer advantage and grow dynamically for several decades.

Second, every transitional country has a lot of distortions, which cause resource misallocation and rent-seeking. It is desirable to remove these distortions. Such distortions are, however, in economic terms, largely endogenous. Unless the causes of a distortion are dealt with, an attempt to remove it can do a lot of harm. If there is a distortion and the economy is in a 'second-best' situation, the removal of the distortion without the removal of the cause will very often make the situation worse. A country embarking on reform should therefore be pragmatically employing transitory protection, as China did in the past four decades.

A careful liberalisation of entry into new sectors consistent with a country's comparative advantages and government facilitation of growth in those sectors can permit it to grow dynamically and preserve stability while preparing the ground for the removal of distortions. A pragmatic approach to develop step by step according to a country's evolving comparative advantage is of great value for developing countries.

At the same time, pragmatism is required in the transition. The final goal is the establishment of a well-functioning market economy, but it should be a process managed by the government paying attention to the needs of all sectors and providing them with business opportunities. In this way, the World Bank's dream of a world free of poverty may be possible.

As for economics, the implication is that in the past most theories were developed for high-income countries. Developing countries use these theories in the hope they will become high-income countries. The intention was good, but the results were often disappointing, due to the differences in the preconditions between developed and developing countries. The applicability of economic theory depends on the preconditions. Policies based on theories generated from the experiences of highincome countries do not, therefore, achieve the intended results in developing countries. It is desirable to develop ideas and theories based on the experiences of developing countries themselves. 
In 2018, China is celebrating the fortieth anniversary of its transition from a planned to a market economy. China's rise from poverty to a world power in the past four decades is a growth miracle unmatched in human history and a goldmine of new development ideas and theories.

\section{References}

Fei, J. and Ranis, G. (1997), Growth and Development from an Evolutionary Perspective, Malden, MA: Blackwell.

Lal, D. and Mynt, H. (1996), The Political Economy of Poverty, Equity, and Growth: A comparative study, Oxford: Clarendon Press.

Lin, J. Y. (1992), Rural reforms and agricultural growth in China, American Economic Review 82: 34-51.

Lin, J. Y. (1995), The Needham puzzle: Why the Industrial Revolution did not originate in China, Economic Development and Cultural Change 43: 269-92. doi.org/10.1086/452150.

Lin, J. Y. (2003), Development strategy, viability and economic convergence, Economic Development and Cultural Change 53: 277-308. doi.org/10.1086/ 367535 .

Lin, J. Y. (2009), Economic Development and Transition: Thought, strategy, and viability, Cambridge: Cambridge University Press. doi.org/10.1017/ CBO9780511805622.

Lin, J. Y. (2011), New structural economics: A framework for rethinking development, World Bank Research Observer 26: 193-221. doi.org/10.1093/ wbro/lkr007.

Lin, J. Y. (2012a), Demystifying the Chinese Economy, Cambridge: Cambridge University Press.

Lin, J. Y. (2012b), The Quest for Prosperity: How developing economies can take off, Princeton, NJ: Princeton University Press.

Lin, J. Y. (2013), Demystifying the Chinese economy, Australian Economic Review 46(3): 259-68. doi.org/10.1111/j.1467-8462.2013.12035.x.

Lin, J. Y. (2014), The Washington consensus revisited: A new structural economics perspective, Journal of Economic Policy Reform 18(2): 96-113. doi.org/10.1080/ 17487870.2014.936439. 
Lin, J. Y. (2017), The rise of China and its implications for economics and other developing countries, Area Development and Policy: 1-11.

Lin, J. Y. and Li, F. (2009), Development strategy, viability, and economic distortions in developing countries, World Bank Policy Research Working Paper No. 4906, Washington, DC: The World Bank.

Lin, J. Y. and Monga, C. (2012), The Growth Report and New Structural Economics, Washington, DC: The World Bank. doi.org/10.1596/978-0-8213-8955-3.

Lin, J. Y. and Tan, G. (1999), Policy burdens, accountability, and soft budget constraints, American Economic Review: Papers and Proceedings 89: 426-31. doi.org/10.1257/aer.89.2.426.

Lin, J. Y., Cai, F. and Li, Z. (2003), The China Miracle: Development strategy and economic reform, Hong Kong: Chinese University Press.

Lin, J. Y., Monga, C., te Velde, D. W., Tendulkar, S. D., Amsden, A., Amoako, K. Y., Pack, H. and Lim, W. (2011), DPR debate: Growth identification and facilitation-The role of the state in the dynamics of structural change, Development Policy Review 29: 259-310. doi.org/10.1111/j.1467-7679.2011. 00534.x.

Lin, J. Y., Wan, G. and Morgan, P. J. (2016), Prospects for a re-acceleration of economic growth in the PRC, Journal of Comparative Economics 44(4): 842-53.

Maddison, A. (2001), The World Economy: A millennial perspective, Paris: OECD Development Centre. doi.org/10.1787/9789264189980-en.

Maddison, A. (2007), Chinese Economic Performance in the Long Run, 2nd edn, Paris: OECD Development Centre.

Maddison, A. (2010), Maddison Historical Statistics, Groningen: Groningen Growth and Development Centre, University of Groningen. Available from: www.ggdc. net/maddison/.

Prebisch, R. (1950), The Economic Development of Latin America and its Principal Problems, New York: United Nations.

Transparency International (2017), Corruption Perceptions Index 2017. Available at: www.transparency.org/news/feature/corruption_perceptions_index_2017.

World Bank (2008), The Growth Report: Strategies for sustained growth and inclusive development, Washington, DC: The World Bank for the Commission on Growth and Development.

World Bank (2018), Global Economic Prospects, Washington, DC: The World Bank. 
This text is taken from China's 40 Years of Reform and Development: 1978-2018, edited by Ross Garnaut, Ligang Song and Cai Fang, published 2018 by ANU Press, The Australian National University, Canberra, Australia.

doi.org/10.22459/CYRD.07.2018.07 